\title{
7 \\ From Development Business to Civil Society? Societal Actors in Development Cooperation
}

\author{
Martin Rempe
}

In March 2005, Siim Kallas, then Vice-President of the Commission and responsible for Administrative Affairs, Audit and Anti-Fraud, in a speech at the European Foundation for Management in Nottingham, made no secret of his aversion to the involvement of non-governmental organizations in European integration: 'Many NGOs rely on public funding, some from the Commission. Annually the Commission channels over 2 billion Euros to developing countries through NGOs... Currently, a lot of money is channelled to "good causes" through organisations we know little about. Noble causes always deserve a closer look. In the Middle Ages the forests of Nottingham were famous for the courageous Robin Hood, the "prince of thieves" who tricked the Sheriff of Nottingham and stole from the rich in order to help the poor. One may regard this legendary figure as an early NGO. His cause seemed noble, but his ways to redistribute wealth were not always quite transparent.'1

Kallas' mistrust of European non-governmental organizations (NGOs) in general and of their role in European Union (EU) development policy in particular seems to have a long tradition in Brussels. Already in 1975, when the Director of the European Development Fund (EDF), Jacques Ferrandi, was asked about the policy of Directorate-General (DG) VIII vis-à-vis the African states, he declared in a more general way that 'our task today is no longer to give them advice but to protect them against bad advisers'. ${ }^{2}$ After cooperation with NGOs was officially launched one year later, the percentage of the Community's total development funding dedicated to NGOs stagnated at around 2.5 per cent between the mid-1980s and the mid-1990s, whereas it increased to 5 per cent in bilateral European aid at the same time. ${ }^{3}$ More recently, the Cotonou agreement, signed in 2000 , called for a share of up to 
15 per cent of the total funds to be directly granted to 'non-state actors', which in this definition includes not only non-profit NGOs but also the private sector. ${ }^{4}$

Non-governmental organizations have been only one type of societal actor among others such as private companies, consulting agencies and research institutes in $\mathrm{EU}$ development cooperation and are the least important by far. However, despite apparent mistrust towards NGOs and their slight numerical significance, the involvement of civil society in EU development cooperation has been a very prominent issue in Brussels for more than ten years. When the EU adopted the notion of 'civil society' for its development policy in 2000, this served a dual purpose: on the one hand, (European) civil society was supposed to become the agent of participatory governance. On the other hand, the building and strengthening of a civil society in the receiver countries became a development goal in itself. ${ }^{5}$ Both objectives reflected highly normative expectations concerning the benefit of civil society's engagement, such as the promotion of liberal democracy, decentralization, pluralism and so on. At the same time, the shift towards civil society in EU development cooperation showed the more general concern of the EU with addressing its (alleged) democratic deficit. Based on ideas of deliberative democracy, the main assumption was that interest representation by European civil society organizations in Brussels, which would observe, monitor, and influence EU policy-making, would enhance the quality of European democracy. ${ }^{6}$

The civil society discourse has engendered a large and partly normative debate in politics and academia.' From a historical perspective, it is striking that the involvement of societal actors appears as a new approach towards development, a claim actually taken for granted in the political science literature. ${ }^{8}$ Against this backdrop, this chapter focuses on the prehistory of contemporary dynamics of development cooperation, when the notions of 'non-governmental organizations' and 'civil society' had not yet been introduced into development discourses. ${ }^{9}$

The chapter will explore the role of societal actors in early European Economic Community (EEC) development cooperation between 1957 and 1975: who were these actors, to what extent did they become more transnational in their constitution and actions, and, finally, how much influence did they exert on EEC development cooperation?

A thorough analysis of this first phase will not only put current debates into a historical perspective; the chapter will also shed new light on the making of EEC development policy. So far, historians have written very little about societal actors in EEC development cooperation, let alone their transnationalization. The existing literature primarily focuses on the negotiations leading up to the Yaoundé and Lomé conventions from an inter-governmental perspective ${ }^{10}$ or is concerned with the particular role of the DG VIII. ${ }^{11}$ Whereas diplomatic historians have highlighted a strong predominance of the French government in EEC development policy, others have placed great emphasis on the influence of Ferrandi, the aforementioned French Director of the EDF.

By contrast, a focus on the role of societal actors will show that EEC development cooperation constituted a complex set of relation. ships among member states, developing countries and the Commission, in which experts, non-profit corporations, private companies and other societal actors interacted and could gain considerable influence. The first section of the chapter analyses how and why societal actors became involved in EEC development cooperation and to what extent they became more transnationally oriented or organized. The second section focuses on one case study from the 1960 s - the improvement of the water supply of Dakar, the capital of Senegal - in order to explore the influence of a German company on the cooperation between the Senegalese government and the EEC. The conclusion will discuss continuity and change in the role of societal actors in EU development policy since the 1970s. It will also return to the ongoing debate on cooperation with NGOs and civil society in this policy field.

\section{Societal actors' involvement in EEC development cooperation}

Originally, development policy was not supposed to become a major field of the EEC's activities. In March 1957, the so-called association of the overseas countries and territories was reluctantly accepted by the West German and Dutch governments as the basis of the EEC's development policy after the French government had insisted on this solution as a precondition for the conclusion of the negotiations. ${ }^{12}$ Nevertheless, after the coming into force of the EEC treaty, this association rapidly gained importance for at least two reasons. Firstly, DG VIII, which was in charge of the association of the overseas territories, was very proactive from the beginning and sought to widen its own institutional influence. ${ }^{13}$ Secondly, as decolonization transformed most of the associated territories into independent states by 1960 , for many of these countries the EEC became the most important aid institution after their respective former colonial power. ${ }^{14}$ 
The EEC treaty included no provision for the involvement of any societal actors in this policy field. However, few policy areas relied so heavily on societal actors and their expertise as development. Its establishment as a distinct policy field went hand in hand with the Verwissenschaftlichung, or the more scientific conceptualization of social relations, ${ }^{15}$ which, in the context of this chapter, means the increasing scientific preoccupation with the political, social, cultural and economic conditions of colonial societies. This process had begun hesitantly in the inter-war years before it accelerated after World War II and reached its heyday in the course of the 1950s, when the apparent certainties of modernization theory and development economics spread across national and international development administrations. ${ }^{16}$ The scientific conceptualization of development was not a special case, however, but embedded in a wider policy-making culture in the 1950s and 1960s that emphasized a scientific approach to finding apparently optimal policy solutions. ${ }^{17}$

Moreover, the project-based character of development cooperation strongly favoured the involvement of societal actors as well. Firstly development planning required expert knowledge, especially in agriculture. With just 50 employees in the beginning, DG VIII was a relatively small administration for its daunting task of managing and coordinating development issues in 18 associated countries. Under these circumstances, the outsourcing of development planning was the only viable way for the Commission to fulfil its treaty obligations. ${ }^{18}$ Thus, it established a close cooperation with research institutes from various member states in the formative phase around 1960. The issue of how to utilize external expertise gained such an importance for the Commission that it even tried to increase its possibilities of awarding research grants and funding - ultimately with success. In 1961, the member states accorded DG VIII considerable financial means from the EDF in order to fund scientific surveys autonomously, that is, without special approval by the representatives of the member states. ${ }^{19}$

Secondly, policy implementation heavily relied on societal actors, too. Development projects such as construction works or agricultural improvement programmes required specialists and were usually awarded in EEC-wide calls for tender. In the area of so-called technical aid, which also included educational programmes, societal actors were equally in demand. In short, without the involvement of societal actors, EEC-level development policy would not have been able to develop. The Commission was aware of this fact and actively sought to cooperate with a broad range of different societal actors right from the beginning.
Scientific institutes as well as individual experts, educational institutions and foundations, business companies and corporations specializing in developmental issues in one way or another became involved in the cooperation with the associated states. To give just a few examples, the German Institut für Wirtschaftsforschung (IFO) and the French Société d'études pour le développement économique et social were instrumental in preparing a general survey on industrialization in associated countries in Africa. Educational institutions like the French Centre d'éducation et d'information européenne (better known as Jeune Europe), the German Carl Duisberg Gesellschaft or, before Britain actually joined the Community in 1973, even the English-speaking Union were responsible for the organization of colloquiums for young Africans studying in Europe. Last but not least, private industrial companies like the German steel company Mannesmann or the French pipework company Pont-à-Mousson engaged in EEC development cooperation just as much as specialized corporations like the private Dutch International Land Development Consultants or the Société d'aide technique et de coopération (SATEC). This latter organization had the legal status of a voluntary non-profit association, but it was in fact managed and controlled by the French state. ${ }^{20}$

Thus, the field of societal actors active in the development policy and projects was highly heterogeneous. Crucially, their functions differed clearly from classical interest representation, which was the main preoccupation of societal actors in other policy areas like agriculture or competition. ${ }^{21}$ In early development cooperation, there were neither general nor special European interests to be represented. The policy outcome concerned first and foremost the societies of the associated states formally represented by their elected governments. In this sense, EEC development cooperation was not so much a policy for Europeans but a policy made by European officials heavily relying on European societal actors.

Hence, different societal actors had different key motivations for engaging in development policy. Private companies had a material business interest in enlarging markets and making profits by selling their products and services. They sought to gain a foothold in the African (development) business. Experts and scientific institutes were driven more by normative ideas of improving the lives of people through technological and scientific progress. They wanted to test their research in practice and get its results accepted by a wider public. Educational institutions and foundations saw their European engagement as an opportunity to acquaint African 
visitors with EEC institutions and to increase their international reputation.

Even if these key motivations differed considerably, they were not necessarily mutually exclusive. Experts could pursue economic interests just as business companies could be convinced to have the best-suited technical solution for a developmental problem. In this sense, it would be misleading to assume a simple dichotomy between material and ideational motivations or to explain different preferences exclusively with differences among societal actors in line with categories such as non-profit versus for-profit actors. What is more, all societal actors shared the belief that they served the morally irreproachable cause of helping people in underdeveloped parts of the world, and this conviction was often combined with a feeling of superiority and condescension towards them. Beyond these general considerations, it is always necessary to study more closely the individual cases, as motivations also depended on the specific developmental issue at stake.

The modalities of how societal actors became involved in development issues varied from proactive engagement to rather passive reactions to requests by the European Commission. Scientists, other experts and those merely implementing programmes tended to react to concrete demands by DG VIII. By contrast, business companies such as Mannesmann actively promoted their engagement in the Community's development because they had a strong profit motivation. However, non-profit corporations like the SATEC also engaged on their own initiative in development cooperation with Africa in order to win long-term project contracts. Thus, technical aid was rather a matter of delegation, whereas project aid was clearly shaped by competition. Interestingly, rivalry regarding project aid was sometimes so strong that societal actors considered their lobbying in African capitals to be just as important as maintaining close connections to the Brussels bureaucracy. ${ }^{22}$

At the same time, the connections to governments and the Commission were clearly much more important for companies than horizontal links to partner companies from other European countries. Indeed, the idea of transnational joint ventures was discussed repeatedly within the Commission and between the member states as a solution to the problem of non-French and especially German companies holding only a small share of EDF contracts. Accordingly, the German government repeatedly requested German industry to align itself with French companies. These appeals usually remained unsuccessful. In general, it seems that the EDF did not particularly encourage transnational joint ventures of companies for at least two reasons: firstly, French business circles as stakeholders in' African markets had little interest in such endeavours, which could have undermined their dominance there. Secondly, they had an influential ally within DG VIII. As a former colonial administrator, EDF Director Ferrandi was, in his own words, very anxious to 'give back to Caesar, what still belongs to him'. ${ }^{23}$ As will be shown in more detail later, he considered the former colonies in Africa still to be in France's backyard and thus clearly privileged French societal actors.

The Commission's attempts at transnationalization on the spot proved similarly ineffective. For instance, the Commission obliged SATEC to Europeanize the project staff in its three-year agricultural modernization programme in the Senegalese peanut areas: 50 per cent of the employees were supposed to come from member states other than France. After one year, however, when the Brussels bureaucracy checked the fulfilment of this contractual obligation for the first time, it turned out that only around 10 per cent were foreigners. Moreover, the French company continued to resist the Europeanization of its teams. It argued that Africanization, which meant replacing the European project staff successively with locals, was much more urgent than Europeanization. ${ }^{24}$

Whereas transnationalization seemed to be difficult in project cooperation due to the societal actors' reluctance, it was more easily achieved in the area of technical cooperation. The colloquium programme and the industrialization survey covering all associated African countries both involved transnational exchange. In both cases, DG VIII was at the origins of these initiatives. The training course for Africans studying in Europe was held in cooperation with educational institutions from all member states. Starting in 1964, these partners regularly met in Brussels to share their experience as well as to harmonize and to improve their individual programmes. ${ }^{25}$ The work on the industrialization survey, which lasted more than two years, became a joint venture of several experts and research institutions from almost the whole Community. ${ }^{26}$ The fact that both activities were general programmes concerning all associated countries certainly favoured these dynamics of transnationalization. Additionally, both measures were part of the technical aid in which national rivalries played only a subordinate role. Nevertheless, it is also remarkable that both activities were initiated and managed not by Fcrrandi's department, but by other departments within DG VIII, which points to the limits of his personal influence. ${ }^{27}$

In conclusion, societal actors right from the beginning in 1958 easily joined EEC development policy and cooperation either proactively or on request. Even though their key motivations may have varied between economic, scientific, normative or prestige concerns, they were 
all driven by self-interest and shared the conviction that they were helping people in what they considered the underdeveloped third world. The EEC institutions welcomed the transnationalization of these societal actors, which was partly achieved. At the same time, there is little evidence that the sheer existence of EEC development policy moved societal actors to deliberately engage in transnational joint ventures or development initiatives, as neo-functionalist theorists assumed at the time. ${ }^{28}$ In the second part of this chapter, I will now check this general finding against the evidence of a concrete case study. It will become clear that if kickstarting transnationalization proved to be a difficult undertaking, its everyday practice was even more intricate.

\section{Societal actors' influence on development cooperation: the Mannesmann case}

Having identified the variety of societal actors and their motives for engagement and forms of involvement in policy-making and implementation, the crucial question of their impact remains to be explored. To what extent did these actors actually influence EEC development cooperation? To explore this question, this section studies one development project, namely, the improvement of Dakar's water supply, from the idea to its completion. This case promises to yield important insights into the extent to which one single business company was able to exert influence on the Community's decision-making process.

Around 1960, Dakar's population was suffering from a water shortage. This shortage first became an issue at the end of the 1930s. In 1945, the gap between demand and supply had already reached more than 15,000 cubic metres per day. In the course of the 1960s, French well drilling in the surroundings of the Senegalese capital was supposed to improve the situation, but these measures were outpaced by rapid population growth. What was more, the quality of the well water decreased over time. Consequently, the water shortage became chronic, especially in the poorer quarters of the city, where public drinking fountains operated only seven hours per day. ${ }^{29}$

After Senegal became independent from France in 1960, the issue of providing Dakar with an adequate water supply was given high priority by the Senegalese government. Alongside the rural modernization of the Senegalese peanut economy, this project became the urban pillar of President Léopold Sédar Senghor's development policy. Very quickly, Mannesmann gained the support of the government for a new concept first presented by its French subsidiary in 1961. Mannesmann's idea was to build an overland pipeline from the Lac du Guiers, located about 300 kilometres north of Dakar. ${ }^{30}$ This pipeline concept promised a reliable and sustainable solution to the problem. By contrast, the French favoured a step-by-step method of well drilling. They did not have an overall concept at that time, and recent test drilling by the Bureau de recherches géologiques et minières had produced only modest results. An advisor of the French finance ministry even suspected that the French companies on the spot had a greater interest in sabotaging the German project than in specifying their own alternative. ${ }^{31}$

At first glance, a further advantage of the German concept was the funding situation for the large-scale pipeline project, which was projected to cost around 100 million German marks. Originally, the German Hermes system was intended to provide debt guarantees for a large part of the project costs. The equivalent French system would cover 17 million German marks for materials to come from French suppliers. However, Raymond Triboulet, the French minister for development, refused to grant such a guarantee. ${ }^{32}$ Therefore, in this early phase, no German-French joint venture was formed either at the level of the businesses or for the funding of the project.

Subsequently, the Senegalese government stuck to its guns and appealed to the EDF in 1964. Its procedure required that DG VIII decide to accept or refuse requests from the associated countries. In case of approval, the responsible directorate would prepare a project proposal to be decided by the EDF committee. This special committee was presided over by the Commission and staffed with representatives from the member states. Decisions required qualified majority (67 out of 100 votes) and votes were allocated according to the financial contributions of the member states to the EDF. Germany and France each had 33 votes, so that at least one more member state representative was needed to pass a project. $^{33}$

However, the Mannesmann case showed a much more complicated decision-making process. To begin with, DG VIII in general and Ferrandi in particular were very sceptical of the idea of the pipeline project right from the beginning. In March 1964, during a visit to Senegal, Ferrandi declared that EDF funding would not be possible since a preliminary agreement with a specific, predetermined company did not conform to the fund's principles of open tendering. Confidentially, however, he told the French ambassador in Dakar, Lucien Paye, that the project could become interesting to the EDF if the French pipework company Pont-à-Mousson were to become aligned with the project. ${ }^{34}$ In other words, behind Ferrandi's formal argument was the fear that the German 
company would take market share from its French competitors on what they considered their own turf.

However, Ferrandi apparently did not push his idea further in Brussels. Instead, DG VIII required two allegedly independent experts from the water departments of the cities of Brussels and The Hague to give their expert opinion. The task was to compare the Mannesmann proposal with the evolving French plans that were still concentrating on well drilling. Influenced by French officials in Dakar as well as in Brussels and Paris, these experts clearly voted for the French solution. Based on their judgement, the EDF formally refused Senegal's request and at the same time announced its support for further drilling. ${ }^{35}$

There are two main reasons why, despite this decision, the case continued to drag on. Firstly, a solution for the water supply of the capital remained one of the most important development issues for Senegal's President Senghor, who wanted to secure the urban population's electoral support. Secondly, in the meantime Mannesmann had succeeded in winning the support of the German government for its proposal. In the light of the pipeline embargo that the North Atlantic Treaty Organization (NATO) had declared against the Soviet Union and the entire eastern bloc at the end of 1962, the government in Bonn welcomed any initiative likely to create new outlets for the German steel industry. ${ }^{36}$ Consequently, the issue of the Dakar water supply became highly politicized between the governments in Paris, Bonn and Dakar and the EEC institutions in Brussels, leading to tensions in FrancoGerman relations and, even more so, between France and Senegal. In both conflicts, Mannesmann engineers acted as experts for the German and Senegalese governments, providing them with technical arguments against the French government backed up by expertise from the Bureau de recherches géologiques et minières.

In spite of the obvious political affiliation of both groups of advisors leading to predictably one-sided opinions, it was hard for the French government to dismiss some arguments advanced by the SenegaleseGerman coalition. Firstly, the French calculations did not consider the urgency of the water scarcity in Dakar. Secondly, the French experts kept quiet about the problem of wells running dry over time and about the decreasing quality of well water. Thirdly, the damage to the countryside that would be caused by drilling in the surroundings of Dakar, leading to the lowering of water tables, and subsequently to desolation and rural exodus, was totally ignored. ${ }^{37}$

Refusing to consider these aspects, the French government not only continued to block participation in the pipeline project but also tried to make the government in Bonn abandon it altogether. Even Mannesmann's renewed and improved offer of a transnational joint venture in the spring of 1965 , foreseeing a share up to 35 per cent of the project for French companies, fell on deaf ears in Paris. ${ }^{38}$ Besides being uneasy about a potential engagement of a German company in Senegal, the French foreign and development ministries particularly feared considerable extra costs for the French treasury. As the guarantor of the Senegalese national budget, France ultimately had to bear the burden for the potentially huge Senegalese debt increase resulting from such a major investment project. ${ }^{39}$

Consequently, the conflict reached a new level. In May 1965, Senghor summoned the French ambassador and told him that never before has France acted like now toward an African country' ${ }^{40}$ Shortly after this, Senghor met the French President Charles de Gaulle in Paris and repeated his harsh criticism. At this stage, de Gaulle finally promised that the French government would no longer act against the pipeline plans. ${ }^{41}$ Thus, joint action by the Senegalese and German governments, both heavily influenced by Mannesmann's expertise and lobbying, weakened the French opposition to the project. As a result, the focus once more turned to the EEC institutions in Brussels. Given de Gaulle's promised neutrality, a second request to the EDF seemed to be likely.

However, the Commissioner for Overseas Development Henri Rochereau was aggrieved that the member states apparently ignored his officials' original decision. The renewed request to the EDF was as unique as it was controversial, so the decision was left to the Commissioners. The request presented the collegiate body with a challenge that threatened to split it down the middle. In the run-up to a meeting at the end of July 1966, it became clear that four Commissioners including the two German ones were in favour of the project while another four, including the two French ones opposed it, which at the same time meant that the latter clearly disagreed with de Gaulle's position of neutrality. The Italian Commissioner for the Internal Market, Guido Colonna di Paliano, seemed undecided. Thus, only political pressure by the German and apparently also the French governments finally made the Commission accept the second request. ${ }^{42}$

It took another year before DG VIII finally submitted a proposal to the EDF committee in summer 1967. The delay was due to Ferrandi's salami tactics - he was deeply disappointed with the Commission's decision and pulled all the strings possible to at least delay the proposal. ${ }^{43}$ Accordingly, the project proposal itself was full of contradictions: DG VIII again referred to the French concept as the better solution and criticized the 
Senegalese government for its stubbornness. From a legal point of view, the Commission's proposal actually left it open for which concept the financial means would be used in the end. ${ }^{44}$ Clearly, DG VIII in general and Ferrandi in particular resented having been outflanked by the competing concept successfully promoted by the German steel company, and they did not intend to give up easily.

The meeting of the EDF committee on 5 July 1967 was perhaps the most remarkable in its history as it led to a showdown between Ferrandi and the member states. According to a report by the German Permanent Representation in Brussels, quoting from secret documents, Ferrandi not only snubbed his boss, the German Director General Heinrich Hendus, but also accused Mannesmann of attempted bribery and accused the Senegalese government of making personal slurs against him. The representatives reached no decision at this meeting. After another week and a formal apology by Ferrandi, the committee met again and the project was finally passed..$^{45}$

Without doubt, Ferrandi's preferences and behaviour were mainly due to his aversion to the German company. From his point of view, Mannesmann had taken over multiple functions that the EDF had never assigned to it. Indeed, Mannesmann acted as planner and advisor, and also wanted to implement the project. The company could take on these functions so successfully because it was supported by the Senegalese and the German governments, which, for different reasons, stood up against the French dominance over EEC development cooperation. In this sense, national as well as transnational coalition building between Mannesmann and member state governments considerably shaped the decision-making process of the pipeline project. By contrast, transnationalization strategies on the business level were not crowned with success.

After his final defeat in the EDF committee, Ferrandi did have his revenge, however, which ironically led to a transnational division of labour, even if it was by no means a voluntary or very effective one. Heavily manipulating the calls for tender, the French Director granted the section of the pipeline financed by the EDF to the French company Pont-à-Mousson, whereas the section funded with national German aid was built by Mannesmann. ${ }^{46}$ Subsequently, the construction of the pipeline was hampered by delays as well as low-quality work. Both seemed to be the result of insufficient communication between the two companies. ${ }^{47}$ The victim proved to be the population of Dakar, whose hopes for a quickly improved water supply were deeply frustrated.
By contrast, the case did not have any consequences in Brussels. In fact, Ferrandi's unilateral action in favour of the French company was so obvious that Mannesmann, in cooperation with the Bundesverband der Deutschen Industrie, the German peak industry association, lobbied in Bonn for the dismissal of the EDF director. The German government, aware of its own role in the politicization of the issue, refrained from such a move in Brussels, however. ${ }^{48}$ This epilogue thus points to the limits of societal actors' scope for action without government support.

\section{Conclusion: from development business to civil society?}

To be sure, not every development project caused such strong political frictions, provoked such heavy dispute over techno-scientific issues, or allowed for such a significant role for societal actors as the project of the Dakar water supply. At the same time, it would be wrong to see this project only as a particular case with no general relevance. Firstly, the Mannesmann case was perhaps unique in terms of the open conflict of national business interests. However, it was quite typical in demonstrating the societal actors' possible scope of influence. They were able to propose and promote their own development projects in the associated states as well as in the EEC institutions. To give but one more example, the EDF's modernization programme in the Senegalese peanut sector was planned and implemented by SATEC. Subsequently, SATEC not only successfully lobbied the Senegalese government as well as DG VIII; in the name of EEC development cooperation, the corporation even shaped the Senegalese reform policy of the peanut sector to a considerable extent in the 1960s. ${ }^{49}$

Secondly, the Mannesmann case shows that vertical support by national governments proved to be much more important for societal actors than horizontal alliances with actors from other member states. This finding underlines the climate of economic nationalism that dominated the project aid of the early EDF. Interestingly enough, the Commission did not attempt to counterbalance such 'national interests', which might have been expected, given its self-perception as a genuine European institution that overrides national ambitions and also keeps in mind the interests of development countries. Instead, through its dogged resistance to the pipeline concept, DG VIII even boosted these national rivalries at a time when the member state governments appeared to have overcome them in this particular case.

Thirdly, the political dimensions of the case also extended to the sphere of technical aid, as became most evident in the politicized expert 
opinion by the experts from the Brussels and The Hague water authorities. However, it seems that in general, technical aid was much less shaped by national rivalries and more open to horizontal transnational cooperation. This may be explained by the smaller material interests of scientists, educational institutions and foundations that initiated advisory processes or were involved by DG VIII.

Fourthly, the pipeline project is a case in point for different types of societal actors engaging in one and the same development project. The German company quarrelled with a French state-owned research institute over the technically best solution for Dakar's water supply. This constellation forced Mannesmann to emphasize its own techno-scientific expertise and subsequently to act in an expert advisory function for the Senegalese and German governments. Thus, the competition among different actors for the same issue or project was just as widespread as one and the same actor taking over different functions such as providing scientific advice, planning and implementing a project. In another example, SATEC was again a direct rival of the private Dutch company ILACO in Senegalese rice cultivation, and both acted as advisors for the Commission and implemented projects on the ground. ${ }^{50}$ These forms of functional and organizational overlap were typical of early EEC development cooperation. This overlap makes impossible any generalizations drawing on simplistic categories such as non-profit and for-profit actors or scientists as advisors and others as implementing projects on the ground. Instead, only a thorough analysis of each case can help to assess the role of distinct societal actors in the contestation over development policy and projects among member states, the Commission and the associated countries in the early phase of European integration.

Finally, does this picture of the engagement of societal actors in early EEC development cooperation look very different from the period after the beginning of the Lomé era in 1975 and its coming to an end in 2000? In this policy field, the Maastricht Treaty had only minor implications for the role of societal actors. The foundation of the present-day EU went along with an explicit and general competence for development policy, which had been lacking in the EEC treaty. Additionally, catchwords such as sustainable development, poverty eradication and especially the promotion of democracy, rule of law, and human rights found their way into the treaty and into European development discourse. Only in 2000 were these issues given substantial content by the Commission, however. Moreover, cooperation with the African, Caribbean and Pacific (ACP) states remained a special relationship regulated outside the treaty by the Lomé conventions. Finally, no reference was made in Maastricht to the role of societal actors in development cooperation. In short, there is much evidence for the conclusion that EU development cooperation has a different temporal logic to that of domestic EU politics and policy-making, and that this logic was structured more by the Lomé and Cotonou conventions. ${ }^{\text {st }}$

With the advent of the Lomé era, the so-called co-financing with European non-governmental organizations introduced in 1976 represented a new budget line, albeit outside of the EDF and with a marginal starting budget of 2.5 million ECU per year. Likewise, in 1975, the NGO-EU Liaison Committee (CLONG) ${ }^{52}$ was established with financial support from the Commission and became a European umbrella organization for national NGOs engaged in developmental issues. It served as a European exchange forum and as a communication channel to the Commission regarding the new budget line and general issues of EEC development policy. ${ }^{53}$ These innovations fit with Akira Iriye's more general observation that the mid-1970s marked the starting point for the involvement of 'global civil society' in development policy and cooperation. ${ }^{54}$ Still, most European aid was channelled through national governments even after the mid-1970s. In this sense, the mechanisms of the engagement of societal actors did not change fundamentally, but their geographical repartition altered incrementally. Thus, the involvement of societal actors from the ACP states can roughly be deduced from the available statistics on EDF contracts. According to these statistics, between 1976 and 1985 (Lomé I and II), about 30 per cent of contracts (project aid and technical assistance) went to partners from the ACP states; by contrast, in the previous period of the second and third funds (1964 to 1975), respectively only 14 and 19 per cent of all contracts had been awarded to actors from the South..$^{55}$

Against the background of this historical record, the shift by the EU towards civil society and participatory development in conjunction with the Cotonou agreement in 2000 seems to amount to a considerable strengthening of the cooperation with NGOs formally launched in 1976. At first glance, the direct cooperation between the EU and NGOs without any governmental interference in the North or the South marks a significant break with the former development business. A historical perspective un this formal change in 2000 would suggest a more sceptical view, however. Firstly, the notion 'non-state actors' of the Cotonou agreement encompasses exactly all of the different types of societal actors that have been involved for more than 50 years already. It only modified the practice of decades in as much as these actors were granted direct access to the EDF. It is inconceivable that contracts are concluded 
with societal actors who are openly hostile to the government of the receiver country. Likewise, direct access to funding as such does not significantly change either the role of societal actors as advisors, planners and implementers or the distribution of power among the different types of societal actors involved. It is not by chance that the Commission has repeatedly emphasized the role of the private sector for the development process in recent years. ${ }^{56}$

Secondly, even if NGOs are not profit-oriented and pursue potentially different approaches towards development, they do not necessarily behave very differently from other societal actors in highly competitive EU development cooperation. Historical research shows very clearly that the organizational form of societal actors does not predetermine distinct functions, let alone lead to especially virtuous conduct. ${ }^{57}$ To give some examples from the recent past, the European NGOs were by no means in agreement with the Commission's strategy of relying more and more on NGOs from the developing countries themselves; after all, they competed with them for financial means and influence. Additionally, they strongly (and partially successfully) opposed the Commission's efforts to cut their ties with the co-financing line, which would have granted access to this source of funding to NGOs from all over the world. ${ }^{58}$ Furthermore, deficient financial documentation practices by CLONG in 2000 led to a severe conflict with the Commission and in the end resulted in the dissolution of CLONG and the foundation of a new organization, the Confederation for Relief and Development. ${ }^{59}$ Another example from a developing country shows that in terms of their range of services, NGOs do not necessarily differ fundamentally from private development companies. Thus, the Senegalese Groupe d'action pour le développement communautaire is recognized by the EU as a NGO. ${ }^{60}$ Its services include planning and the evaluation of projects, the conducting of surveys and the execution of projects ${ }^{61}$ - in short, very similar functions to those that societal actors, including business actors like Mannesmann, fulfilled in the 1960s. More generally, an evaluation of the EU's development programme in Ghana in the first years of the 2000 s concluded that it 'remains a traditional aid programme, socio-economic in orientation, with almost no political component and no attention to civil society strengthening. This is quite extraordinary given the high level policy rhetoric emanating from Brussels for well over a decade on democracy promotion in general and strengthening civil society in particular.' ${ }^{62}$

Thus, all of these findings and cases cast doubt on the assumption that the involvement of civil society represents a completely new approach in the EU's development policy. The normative expectations regarding the role of civil society in EU development cooperation could not and cannot be met easily. Firstly, this 'third sector' between the market and the state is too heterogeneous and frequently too closely entangled with both of the other sectors. ${ }^{63}$ Secondly, a narrower focus on NGOs is not only misleading due to their limited significance; it also reveals the contradictions between the normative expectations as to their mode of action and their actual behaviour in the EU development field. Overall, the Commission's emphasis on civil society seems to represent a rhetorical shift more than a substantial new development strategy. The fact that in 2002 no societal actor was consulted before the Commission published its communication on the participation of non-state actors amounts to more than just a procedural error. ${ }^{64}$ It reflects the EU's difficulties in coming to terms and transforming its state-focused and business-oriented heritage in development cooperation. Present-day EU development cooperation does not primarily involve a normatively 'good' European civil society participating in development policy and projects and giving aid in order to build Africa in its own image. Rather, it is a complex political process shaped by competition and conflict among member state governments, EU institutions and, last but not least, societal actors.

\section{Notes}

1. Siim Kallas, The Need for a European Transparency Initiative. Speech Held at the European Foundation for Management, Nottingham Business School 3 March 2005, available from <http://europa.eu/rapid/pressReleasesAction do? reference $=S P E E C H / 05 / 130>$ (accessed 30 April 2012). I would like to thank Wolfram Kaiser and Jan-Henrik Meyer as well as Heike Wieters for their helpful comments on earlier drafts of this chapter.

2. Le 'patron' du FED s'en va, in: Le Soleil, Dakar, 10 December 1975, Centre des Archives diplomatiques (CAD), Dakar, AMB 758.

3. Chris Dammers, The European Union and NGOs: An Ever-expanding Relationship? in: Marjorie Lister (ed.), The New Europe: Interdisciplinary Perspectives, Boulder, CO: Westview, 1999, 85-102, 85.

4. Group of African, Caribbean and Pacific States, ACP-EU Partnership Agreement Signed in Cotonou on 23 June 2000, Brussels: European Commission, 2003 Article 6.

5. European Commission, The European Community's Development Policy. Statement by the Council and the Commission, Luxembourg: Office for Official Publications of the European Communities, 2000; Gordon Crawford, The European Union and Strengthening Civil Society in Africa, in: Maurizio Carbone and Marjorie R. Lister (eds.), New Pathways in International 
Development: Gender and the Civil Society in EU Policy, AIdershot: Ashgate, 2006, 139-58, 139-40.

6. See the introduction to this volume; also Jan W. van Deth and William A. Maloney, Introduction: From Bottom-Up and Top-Down Multi-level Governance in Europe, in: idem (eds.), Civil Society and Governance in Europe. From National to International Linkages, Cheltenham: Edward Elgar, 2008, 3-18, here 4-9.

7. To cite only a few different concepts from a huge literature: Stephen R. Hurt, Civil Society and European Union Development Policy, in: Maurizio Carbone and Marjorie R. Lister (eds.), New Pathways in International Devel. opment: Gender and the Civil Society in EU Policy, Aldershot: Ashgate, 2006, 109-22; Jürgen Kocka, Zivilgesellschaft in historischer Perspektive, in Forschungsjournal Neue Soziale Bewegungen, vol. 16, no. 2 (2003), 29-37; Sven Reichardt, Civil Society: Notes on the Revival of a Concept, in: Sven Eliaeson (ed.), Building Democracy and Civil Socicty East of the Elbe. Essays in Honour of Edmund Mokrzycki, London: Routledge, 2006, 17-28; Thomas Fetzer Zivilgesellschaftliche die Horausbildung Organisationen in Europa nach 1945: Katalysatoren für Kirsch und Alexander (eds.), Transnationale Öffentlichkeiten und Identitäten im 20. Jahrhundert, Frankfurt: Campus, 2002, 355-92; Roland Roth, Die dunklen Seiten der Zivilgesellschaft. Grenzen einer zivilgesellschaftlichen Fundierung von Demokratie, in: Forschungsiournal Neue Soziale Bewegungen, vol. 16, no. 2 (2003), 59-73; Nelson Kasfir, Civil Society, the State and Democracy in Africa, in: Commonwealth \& Comparative Politics, vol. 36 , no. 2 (1998), 123-49.

8. Jean Bossuyt, Mainstreaming Civil Society in ACP-EU Development Cooperation, in: Maurizio Carbone and Marjorie R. Lister (eds.), New Pathways in International Development: Gender and the Civil Society in EU Policy. Aldershot: Ashgate, 2006, 123-38, here 123-5; also Maurizio Carbone, European NGOs in EU Development Policy: Between Frustration and Resistance, in: idem and Marjorie R. Lister (eds.), New Pathways in International Development: Gender and the Civil Society in EU Policy, Aldershot: Ashgate, 2006, 197-210; Valentina Bettin, NGOs and the Development Policy of the European Union, in: Pierre-Marie Dupuy and Luisa Vierucci (eds.), NGOs in International Law. Efficiency in Flexibility? Cheltenham: Edward Elgar, 2008, 116-34; Dammers, European Union; Hurt, Civil Society.

9. Even if 'non-governmental organizations' were already mentioned in the 1945 UN Charter, the term gained broader relevance only in the 1970s, se Peter Willets, Non-Governmental Organizations in World Politics. tion of Global Governance, London: Routled a century-old notion, was rediscover a century-old notion, was rediscovered only in the 1970s and 1980s in Latin America and in the eastern bloc by oppositional movements, see Reichardt,
Civil Society, 17-18.

10. Urban Vahsen, Eurafrikanische Entwicklungskooperation. Die Assoziierungspolitik der EWG gegenüber dem subsaharischen Afrika in den 1960er Jahren, Stuttgart: Steiner, 2010; Guia Migani, La France et l'A frique sub-saharienne, Stuttgart: 1963: histoire d'une décolonisation entre lafrique sub-saharienne, $1957-$ de puissance, Brussels: PIE, 2008; Thomas Moser, Europäische Integration Dekolonisation, Eurafrika: eine historische Analyse über Entstchungsbedingungen der Eurafrikanischen Gemeinschaft von der Weltwirtschaftskrise bis zum JaundeVertrag, 1929-1963, Baden-Baden: Nomos, 2000; Lili Reyels, Die Entstehung des ersten Vertrags von Lomé im deutsch-französischen Spannungsfeld 19731975, Baden-Baden: Nomos, 2008; Jean-Marie Palayret, Mondialisme contre régionalisme: $C E E$ et $A C P$ dans les négociations de la convention de Lomé 1970-75, in: Antonio Varsori (ed.), Inside the European Community. Actors and Policies in the European Integration 1957-1972, Baden-Baden: Nomos, 2006, 369-97.

11. Véronique Dimier, Bringing the Neo-Patrimonial State back to Europe. French Decolonization and the Making of European Development Aid Policy, in: Archiv für Sozialgeschichte, vol. 48 (2008), 433-57; Véronique Dimier, Institutionnalisation et bureaucratisation de la Commission Européenne: L'exemple de la DG Développement, in: Politique Européenne, no. 11 (2003), 99-121.

12. Rik Schreurs, L'Eurafrique dans les négociations du Traité de Rome, 19561957, in: Politique Africaine, no. 49 (1993), 82-92.

13. Véronique Dimier, Négocier avec les rois nègres: L'influence des administrateurs coloniaux français sur la politique européenne de développement, in: Marie-Thérèse Bitsch and Gérard Bossuat (eds.), L'Europe unie et l'Afrique: de l'idée d'Eurafrique à la convention de Lomé I, Baden-Baden: Nomos, 2005, 393-409.

14. Martin Rempe, Entwicklung im Konflikt, Die EWG und der Senegal, Köln: Böhlau, 2012; Vahsen, Eurafrikanische Entwicklungskooperation.

15. Lutz Raphael, Die Verwissenschaftlichung des Sozialen als methodische und konzeptionelle Herausforderung für eine Sozialgeschichte des 20 . Jahrhunderts, in: Geschichte und Gesellschaft, vol. 22, no. 2 (1996), 165-93.

16. Frederick Cooper, Development, Modernization and the Social Sciences in the Era of Decolonization: The Examples of British and French Africa, in: Revue d'Histoire des Sciences Humaines, no. 10 (2004), 9-38; for the interwar period see Gary Wilder, Colonial Ethnology and Political Rationality in French West Africa, in: History and Anthropology, vol. 14, no. 3 (2003), 219-52; on the emergence of the modernization theory see Nils Gilman, Mandarins of the Future. Modernization Theory in Cold War America, Baltimore, MD: Johns Hopkins University Press, 2003.

17. In general, see Peter Weingart, Die Stunde der Wahrheit? Zum Verhältnis der Wissenschaft zu Politik, Wirtschaft und Medien in der Wissensgesellschaft, Weilerswist: Velbrück Wissenschaft, 2001; a good example is the scientification of the German economic policy, see Alexander Nützenadel, Stunde der Ökonomen. Wissenschaft, Politik und Expertenkultur in der Bundesrepublik 1949-1974, Göttingen: Vandenhoeck \& Ruprecht, 2005.

18. The same argument is put forward by Justin Greenwood, Interest Representation in the European Union (Second edition), Basingstoke: Palgrave Macmillan, $2007,7$.

19. Interview Ferrandi, 28 and 29 May 2004, Historical Archives of the European Union (HAEU), INT 711, 12; Carol Cosgrove-Twitchett, Europe and Africa. From Association to Partinership, Farnborough: Saxon House, 1978, 52-5; on the beginnings of the DG VIII, see also the personal record of the first Commissioner Robert Lemaignen, L'Europe au berceau. Souvenirs d'un technocrate, Paris: Plon, 1964. 

20. Rempe, Entwicklung im Konflikt. The SATEC was managed by a directorate incherent French ministries. However, in legal terms, it was constituted as a private non-profit associaTab in accordance with the so-called loi de 1901. See Claudine Enjalbert, Tableau des institutions, in: Esprit, no. 38 (1970), 13-36, 23f.

21. See, for example, chapters 4 and 6 , this volume.

22. Martin Rempe, Fit für den Weltmarkt in fünf Jahren? Die Modernisierung der senegalesischen Erdnusswirtschaft in den 1960er Jahren, in: Hubertus Büschel and Daniel Speich (eds.), Entwicklungswelten: Globalgeschichte der Entwicklungszusammenarbeit, Frankfurt: Campus, 2009, 241-74.

23. Vahsen, Eurafrikanische Entwicklungskooperation, 362-8; also Volker Alberts and Jürgen Bellers, Die Bundesrepublik Deutschland und die Entwicklungspolitik der Europäischen Gemeinschaft 1957-1983, Münster: LIT,
1986, 37-42.

24. Rempe, Entwicklung im Konflikt, 145-6. 25. DG VIII, Compte rendu de la réunion, 12 July 1965, HAEU 25/1980-
$1102,67$.

26. DG VIII, Composition des équipes participant au programme d'étude sur l'industrialisation des EAMA, no date [1965], HAEU 25/1980-1993, 28.

27. The survey was conducted by the department for planning headed by the Belgian Director Jean Durieux. The Dutch Director Jean Jacques van der Lee and his department for general affairs were responsible for the Colloquia. 28. Ernst B. Haas, The Uniting of Europe, Stanford, CA: Stanford University Press,
1958.

29. Bineta Gueye, Croissance démographique et approvisionnement en eau courante de la ville de Dakar, Sénégal (1945-1971), Ph.D., Paris: Université Paris Diderot,
1998, 160-90.

30. Obadiah Mailafia, Europe and Economic Reform in Africa. Structural Adjustment and Economic Diplomacy, London: Routledge, 1997, 59f.; Vahsen, Eurafrikanische Entwicklungskooperation, 359-62.

31. Tschaikowsky, Note, 23 June 1961, Centre d'accueil et de recherche des Archives nationales (CARAN), Fonds Foccart public (FPU) 55/4.

32. Török, Note, 23 March 1965, Political Archive of the Federal Foreign Office (PAAA), B 68-635; Senghor to Erhard, 15. March 1965, ibid.; Mannesmann to Auswärtiges Amt, 21 January 1970, Annexe: Memorandum, PAAA, Auslandsvertretung (AV) 7313; Auswärtiges Amt to Embassy Dakar, 27 July
1964, PAAA, AV 7312.

33. Cosgrove-Twitchett, Europe and Africa, 105-6.

34. Paye to Triboulet, not dated [March 1964], CAD, Dakar AMB 288.

35. Mission d'aide et de coopération to ministère de la Coopération, 29 October1964, CAD, Dakar MCAC 431; Rochereau to Senghor, 25 February 1965, PAAA, B 68-635; citations also in Rempe, Entwicklung im Konflikt, 182f

36. On the background of the embargo and the German debate Karsten Rudolph Wirtschaftsdiplomatie im Kalten Krieg. Die Ostpolitik der deutschen Großindustrie 1945-1991, Frankfurt: Campus, 2004, 164-71.

37. Ministère de la Coopération, Note, 5 May 1965, PAAA, B 68-635; Mannesmann, Memorandum - Wasserversorgung der Stadt Dakar, not dated [May 1965], ibid.; Török, Note, 5 May 1965, ibid.
38. Török, Note, 31 May 1965, PAAA, B 68-635; Ergebnisniederschrift der 7. deutsch-französischen Konsultationen über die Zusammenarbeit im Bereich der Entwicklungshilfe, 9 July 1965, ibid.; Compte-rendu 7ème comité franco-allemand sur l'aide aux pays sous-développés, 16 July 1965 Archives du ministère des Affaires étrangères, Paris (AMAEF), Sénégal 102.

39. Note pour le secrétariat d'état chargé de la Coopération, 2 May 1965, AMAEF, Sénégal 102.

40. Telegramme Embassy Dakar to ministère des affaires Étrangères français, 20 May 1965, AMAEF, Sénégal 102.

41. Couve de Murville to de Lagarde, July 1965, in: Ministère des affaires Étrangères (ed.), Documents diplomatiques français 1965, Brussels: PIE, 2005 166f.; ministère des affaires Étrangères français to Représentation permanente Brussels, 29 July 1965, AMAEF, Sénégal 102; Direction des affaires africaines et malgaches, Note, 25 July 1965, ibid. To be sure, de Gaulle stated that France had not at any time actively obstructed the plans.

42. Commentaire Brunet sur la note du 27.5.1966, 3 June 1966, AMAEF Sénéga 102; Rochereau to Lahr, 13 July 1966, PAAA, B 68-636; Ständige Vertretung Brüssel to Auswärtiges Amt, 9 June 1966, ibid.

43. See for details Rempe, Entwicklung im Konflikt, 190-1.

44. DG VIII, Proposition de financement 'Extension de l'adduction d'eau de Dakar', 27 April 1967, AMAEF, Sénégal 102.

45. Moltrecht, Note, 5 July 1967, PAAA, B 68-636; Schnabel, Note, 7.7.1967, ibid.

46. Junges, Vermerk, 24 March 1970, PAAA, AV 7313; for further details see Rempe, Entwicklung im Konflikt, 195.

47. Mannesmann to Auswärtiges Amt, 21 January 1970, annexe, PAAA, AV 7313; Embassy Dakar, Note, 17 November 1970, ibidem; Contrôleur délégué, Deuxième rapport sur l'état d'avancement des travaux, November 1970 Archives of the EU Delegation in Senegal, II. FED 211015016.

48. Mannesmann Office Senegal to Mannesmann Düsseldorf, 30 March 1970 PAAA, AV 7313; Junges to Auswärtiges Amt, 1 July 1970, ibid.; Everling to DG VIII, 24 November 1970, ibid.

49. See in detail Rempe, Fit für den Weltmarkt, 264-7.

50. See Rempe, Entwicklung im Konflikt, 262-77, especially 271-4.

51. Nico Schrijver, The EU's Common Development Cooperation Policy, in: Mario Telò (ed.), The European Union and Global Governance, London: Routledge, 2009, 176-91; Gabriele Bäcker, Kompetenzverteilung und Entscheidungsverfahren in der europäischen Entwicklungszusammenarbeit nach Maastricht, Bochum: Institut für Entwicklungsforschung und Entwicklungspolitik, 1994, 34f.; Michèle Knodt and Xandra Schnurre-Weiß, Entwicklungspolitik, in: Hubert Heinelt and Michèle Knodt (eds.), Politikfelder im EU-Mehrebenensystem. Instrumente und Strategien europäischen Regierens, Baden-Baden: Nomos, 2008, 81-96.

52. The French acronym is common in the literature: Comite de liaison des organisation non-gouvernementale.

53. João de Deus Pinheiro, Introduction, in: European Commission (ed.), Partners in Development. The European Union and NGOs, Luxembourg: Office for Official Publications of the European Communities, 1995, 5, 17; Carbone, European NGOs, 199-202. 
54. Akira Iriye, Global Community. The Role of International Organizations in the Making of the Contemporary World, Berkeley, CA: University of California Press, 2004, 126-56, especially 141-3.

55. The exact figures are the following: Fourth EDF 29.7 per cent and fifth EDF 27.4 per cent, see Directorate-General for Development of the Commission of the European Communities, Ten years of Lomé. A Record of ACP-EEC Partnership 1976-1985. Report on the Implementation of Financial and Technical Cooperation under the First Two Lomé Conventions, Luxembourg: Commission of the European Communities, 1986, 58; Cosgrove-Twitchett, Europe and Africa, 135.

56. Hurt, Civil Society, 115-6.

57. With reference to USAID, a similar argument is put forward by Rubén Berrios, Contracting for Development. The Role of For-Profit Contractors in U.S. Foreign Development Assistance, London: Praeger, 2000, 53-61.

58. Carbone, European NGOs, 198-202.

59. Berthold Kuhn, Entwicklungspolitik zwischen Markt und Staat: Möglichkeiten und Grenzen zivilgesellschaftlicher Organisationen, Frankfurt a.M.: Campus, 2005, 183; Carbone, European NGOs, 201-2.

60. Communication of the Commission on the Participation of Non-States Actors in EC Development Policy, COM (2002) 598 final, 7 November 2002, 40-1, available from: <http://eur-lex.europa.eu/LexUriServ/site/en/ com/2002/com2002_0598en01.pdf> (accessed 4 May 2012).

61. On the services offered by the NGO, see the list of consulting agencies provided by the Senegalese Agence de Développement et d'Encadrement des Petites et Moyennes Entreprises on its website, available from <http://www. senegal-entreprises.net/consultants.htm > (accessed 5 May 2012).

62. Crawford, European Union, 145

63. A similar argument is put forward by Roth, Zivilgesellschaft, 69-71.

64. Hurt, Civil Society, 110, 112, 116; Carbone, European NGOs, 204-5. 